\title{
PENERAPAN PROBLEM BASED LEARNING DAN MEDIA FLIPCART UNTUK MENINGKATKAN HASIL BELAJAR IPA MATERI EKOSISTEM SISWA
}

\author{
Nita Retno Wayuningati \\ SD Negeri Sukoharjo 2 Malang, Jalan Prof. Moch Yamin V-25 Klojen Malang \\ Email: zheenit@gmail.com
}

\begin{abstract}
This study aims to describe the application of problem based learning (PBL) and flipcard media to improve the learning outcomes of science materials of students' ecosystem VII Grade Semester SDN Sukoharjo 2 Malang. The research design used is classroom action research (CAR). The implementation of CAR refers to the CAR cycle model by Kemmis and Taggart covering four stages: planning, action execution, observation, and reflection. The results showed that: (1) before the action the average score of students was $74.1 ;(2)$ in the first cycle of learning result has increased that is the average student become student 79.33; and (3) in Cycle II and average student learning outcomes 81.60. The implementation of science learning of ecosystem material by applying PBL model and flipcard media in Cycle I and Cycle II are 76.83 and 86.84 with good criteria.
\end{abstract}

Keywords: problem-based learning, flipcart media, student learning outcomes

\begin{abstract}
Abstrak: Penelitian ini bertujuan mendeskripsikan penerapan penerapan problem based learning (PBL) dan media flipcard untuk meningkatkan hasil belajar IPA materi ekosistem siswa Kelas V Semester SDN Sukoharjo 2 Malang. Rancangan penelitian yang digunakan adalah penelitian tindakan kelas (PTK). Pelaksanaan PTK mengacu pada model siklus PTK oleh Kemmis dan Taggart meliputi empat tahap, yaitu perencanaan, pelaksanaan tindakan, pengamatan, dan refleksi. Hasil penelitian menunjukkan bahwa: (1) sebelum tindakan nilai rata-rata siswa adalah 74,1 ; (2) pada Siklus I hasil belajar mengalami peningkatan yaitu rata-rata siswa menjadi siswa 79,33; dan (3) pada Siklus II dan rata-rata hasil belajar siswa 81,60. Keterlaksanaan pembelajaran IPA materi ekosistem dengan menerapkan model PBL dan media flipcard pada Siklus I dan Siklus II masing-masing 76,83 dan 86,84 dengan kriteria baik.
\end{abstract}

Kata kunci: problem based learning, media flipcart, hasil belajar siswa

Pencapaian hasil pembelajaran IPA yang sesuai dengan tujuan kurikulum tentunya perlu dilaksanakan dengan memperhatikan beberapa komponen. Berdasarkan tujuan IPA tersebut tampak bahwa dalam kegiatan pembelajaran IPA mempunyai komponen guru, siswa, dan lingkungan sekitar. Guru merupakan salah satu komponen pendidikan yang sangat penting dalam dunia pendidikan, sehingga guru dapat dikatakan sebagai ujung tombak pendidikan. Dalam konteks ini, guru mempunyai peranan yang sangat besar dan strategis, yaitu sebagai pendidik dan pengajar. Menurut Mulyasa (2007) guru adalah pendidik yang menjadi tokoh, panutan, dan identifikasi para peserta didik, dan lingkungannya.

Bagi anak yang masih duduk di bangku sekolah dasar khususnya Kelas V SD perlu adanya semacam rangsangan atau motivasi agar anak mau berpikir secara kritis, mau untuk bertukar pikiran dengan teman sebayanya agar informasi yang didapat juga berkembang. Maka langkah yang dapat dilakukan oleh seorang guru, yaitu bisa dengan menggunakan model- model pembelajaran yang bervariasi. Hal ini bertujuan agar minat atau motivasi belajar yang berasal dari diri anak bisa muncul dan berdampak baik bagi diri siswa sendiri. Piaget 
menyatakan bahwa usia anak sekolah dasar (umur 7 s.d. 12 tahun) masuk dalam kategori tahap operasional konkret (Budiningsih, 2005). Pada tahap ini anak telah memiliki kecakapan berpikir logis, akan tetapi hanya pada benda yang yang bersifat konkret saja. Sehingga siswa Kelas V perlu melalui proses belajar yang konkret dan dialami sendiri oleh siswa untuk mencapai tujuan pembelajaran yang diharapkan guru sesuai dengan standar kompetensi yang akan dicapai.

Berdasarkan hasil pengamatan yang dilakukan oleh peneliti di SDN Sukoharjo 2 Malang diketahui siswa mengantuk saat diterangkan, siswa tidak selesai mengerjakan tugas, siswa mengganggu konsentrasi temannya yang sedang mengerjakan, siswa bermain sendiri bahkan kadang menggambar dan menulis kesenangan mereka di buku tulisnya, siswa tidak mengerjakan pekerjaan rumah (PR) yang diberikan gurumeskipun sedikit, siswa tidak mau bertanya apa yang belum dan yang sudah dikuasai, dan siswa tidak bisa menjawab pertanyaan guru terkait materi pembelajaran yang sudah diajarkan.

Kenyataan di lapangan, di sekolah khususnya di SD, siswa masih banyak yang mengalami kesulitan mempelajari ekosistem Hal ini terlihat dari masih rendahnya hasil belajar mata pelajaran IPA, Bertitik tolak dari hal tersebut di atas perlu dicari penyebabnya, tindakan-tindakan yang harus dilakukan agar siswa dalam mempelajari konsepkonsep ekosistem tidak mengalami kesulitan, sehingga indikator yang dibuat oleh guru mata pelajaran IPA dapat tercapai dengan baik dan hasilnya dapat memuaskan semua pihak. Hasil observasi dokumen sekolah menunjukkan rata-rata hasil ulangan harian sebanyak 3 Kompetensi Dasar (KD) yang dilakukan oleh guru kelas $\mathrm{V}$ tercatat hanya mencapai rata-rata 74 dari 30 siswa hanya 17 siswa (56,67\% siswa) yang mampu mencapai ketuntasan, sedangkan 13 siswa (43,33\% siswa) masih di bawah Kriteria Ketuntasan Minimum (KKM) yang telah ditentukan Sekolah Dasar Negeri Sukoharjo yaitu 75. Hasil ini didukung oleh data yang diperoleh dari wawancara yang dilakukan dengan guru ( kapan) yang menginformasikan bahwa berbagai variasi yang dapat dikembangkan oleh guru dalam proses pembelajaran. Guru pernah menggunakan metode (diskusi, klasikal, tanya jawab, demonstrasi, berpasangan, problem solving), guru pernah menggunakan media (gambar, benda konkrit, dan power point), guru melakukan pengamatan terhadap sikap moral dan spiritual, dan guru memberikan penilaian proyek dan portofolio. Akan tetapi semua yang sudah dilakukan guru masih belum mencapai hasil optimal yang akan dicapai yaitu hasil belajar siswa masih di bawah klasikal baik secara individu maupun klasikal. Maka dari itu perlu diterapkan model dan media lainnya untuk mengatasi permasalahan yang sedang dialami.

Salah satu alternatif pembelajaran untuk mengatasi permasalahan siswa Kelas V di SDN Sukoharjo 2 Malang yaitu pembelajaran berbasis masalah (problem based learning). Pembelajaran PBL akan membantu siswa dan guru dalam proses belajar melalui situasi dunia nyata siswa dan akan mendorong siswa membuat hubungan pengetahuan yang dimiliki dengan penerapannya dalam kehidupan sehari-hari. Hal itu dikarenakan karena PBL memiliki tiga karakteristik yang digambarkan dalam pelajaran, yaitu: (1) pelajaran berfokus pada pemecahan masalah; (2) tanggung jawab untuk memecahkan masalah bertumpu pada siswa; dan (3) guru mendukung proses saat siswa mengerjakan masalah (Eggen dan Kauchak, 2012).

Selain model, diperlukan juga media pembelajaran sebagai alat komunikasi antara guru dan siswa supaya terjadi interaksi dua arah antara guru dengan siswa. Media pengajaran mempunyai manfaat yang beragam seperti yang dinyatakan Sudjana (2010) yaitu: (1) pengajaran akan lebih menarik perhatian siswa sehingga dapat menumbuhkan motivasi belajar; (2) bahan pengajaran akan lebih jelas maknanya sehingga dapat dipahami oleh para siswa dan memungkinkan menguasai tujuan pengajaran lebih baik; (3) metode mengajar akan lebih bervariasi, tidak semata-mata komunikasi verbal melalui penuturan kata-kata oleh guru sehingga siswa tidak bosan dan guru tidak kehabisan tenaga, apalagi kalau guru mengajar setiap jam pelajaran; dan (4) siswa lebih banyak melakukan kegiatan belajar, sebab tidak hanya mendengarkan uraian guru, tetapi juga aktivitas lain seperti mengamati, melakukan, mendemonstrasikan dan lain-lain.

\section{METODE}

Jenis penelitian yang dilakukan dalam penelitian ini adalah penelitian tindakan kelas (class action research). Penelitian Tindakan Kelas (PTK) 
adalah proses investigasi terkendali untuk menemukan dan memecahkan masalah pembelajaran di kelas, proses pemecahan masalah tersebut dilakukan secara bersiklus, dengan tujuan untuk meningkatkan kualitas pembelajaran di kelas tertentu (Akbar, 2010). Terdapat empat tahapan PTK yang dilalui, yaitu: (1) perencanaan; (2) pelaksanaan; (3) pengamatan; dan (4) refleksi seperti yang dikemukakan oleh Kemmis dan McTaggart (1982). Subyek dalam penelitian ini adalah siswa Kelas VI SDN Sukoharjo 2 Malang, sebanyak 30 orang siswa yang terdiri dari 16 siswa laki-laki dan 14 siswa perempuan.

Teknik pengumpulan data dalam penelitian ini ialah observasi, dokumentasi, dan tes. Data yang telah terkumpul akan dianalisis secara deskriptif, baik deskriptif kualitatif maupun deskriptif kuantitatif. Data kualitatif berupa observasi pembelajaran akan dianalisis dengan analisis kualitatif dengan tahapan: pemaparan data, reduksi-penyederhanaan data, kategorisasi data-pengelompokan data sesuai fokus masalah, refleksi dan pembahasan. Sedangkan data akan dianalisis secara deskriptif kuantitatif adalah data tentang aktivitas belajar siswa meliputi ranah afektif (sikap), ranah psikomotor (keterampilan) siswa yang dikumpulkan melalui cek list pada lembar observasi yang disertai rubrik penilaian siswa.

\section{HASIL}

\section{Keterlaksanaan Pembelajaran Siklus I dan II}

Pembelajaran pada setiap pertemuannya dapat diterapkan dengan baik dan berhasil merubah kegiatan pembelajaran yang bersifat teacher centered menjadi student centered. Guru dapat menerapkan model PBL pada pembelajaran IPA sesuai dengan langkah model pembelajaran meliputi: (1) memberikan orientasi tentang permsalahan kepada peserta didik, (2) mengorganisasikan peserta didik utuk meneliti, (3) membantu investigasi mandiri atau kelompok, (4) mengembangkan dan mempresentasikan artefak dan exhibit, dan (5) menganalisis dan mengevaluasi proses mengatasi masalah. Keterlaksanaan pembelajaran IPA materi ekosistem dengan menerapkan model PBL dan media flipcard pada Siklus I dan Siklus II masing-masing 76,83 dan 86,84 dengan kriteria baik.

\section{Hasil Belajar Siklus I dan Siklus II}

Data tentang hasil belajar siswa diperolah pada pratindakan, siklus I, dan siklus II. Nilai rata-rata hasil ulangan harian sebanyak $3 \mathrm{KD}$ yang dilakukan oleh guru Kelas V tercatat hanya mencapai rata-rata 74 dari 30 siswa hanya 17 siswa (56,67\% siswa) yang mampu mencapai ketuntasan, sedangkan 13 siswa (43,33\% siswa) masih di bawah Kriteria Ketuntasan Minimum (KKM) yang telah ditentukan Sekolah Dasar Negeri Sukoharjo yaitu 75. Hasil belajar yang diperoleh siswa yaitu: terdapat 23 siswa sudah tuntas, 7 siswa belum tuntas. Ketuntasan siswa diperoleh dari KKM yang ditetapkan sekolah.

Pada Siklus I hasil dari skor yang diperoleh seluruh siswa didapat 2380 , kemudian dicari ratarata kelas yaitu skor yang diperoleh di bagi jumlah siswa di dapat rata- rata 79,33 dengan kriteria nilai baik. hasil belajar yang diperoleh siswa yaitu: terdapat 26 siswa $(86,67 \%)$ sudah tuntas, 4 siswa $(13,33 \%)$ belum tuntas. Ketuntasan siswa diperoleh dari KKM yang ditetapkan sekolah. Pada siklus II hasil dari skor yang diperoleh seluruh siswa didapat 2448, kemudian dicari rata- rata kelas yaitu skor yang diproleh di bagi jumlah siswa di dapat ratarata 81,60 dengan kriteria nilai baik. hasil belajar yang diperoleh siswa, yaitu terdapat 26 siswa $(86,67 \%)$ sudah tuntas, 4 siswa $(13,33 \%)$ belum tuntas. Ketuntasan siswa diperoleh dari KKM yang ditetapkan sekolah. Hasil dari skor yang diperoleh seluruh siswa didapat 2448 , kemudian dicari ratarata kelas yaitu skor yang diproleh di bagi jumlah siswa di dapat rata- rata 81,60 dengan kriteria nilai baik.

Hasil penelitian menunjukkan bahwa: (1) sebelum tindakan nilai rata-rata siswa adalah 74,1 ; (2) pada siklus I hasil belajar mengalami peningkatan yaitu rata-rata siswa menjadi siswa 79,33; dan (3) pada siklus II dan rata-rata hasil belajar siswa 81,60 . Kesimpulan dari penelitian ini adalah penerapan PBL dan media flipcart dapat meningkatkan hasil belajar siswa. Peningkatan hasil belajar siswa dapat dilihat pada Tabel 1 .

Berdasarkan Tabel 1 dapat diketahui hasil belajar siswa mengalami kenaikan 6,35 (9,40\%). Oleh karena itu, selanjutnya dilakukan tindakan Siklus II yang diharapkan dapat lebih meningkatkan hasil belajar siswa. Tabel 2 adalah perbandingan hasil belajar siswa antara Siklus I dan Siklus II. 
Berdasarkan Tabel 2 dapat disimpulkan bahwa pemahaman konsep matematika melalui hasil belajar siswa mengalami peningkatan sebanyak 15,42 $(20,87 \%)$. Hal ini berarti bahwa penerapan media papan lipat pecahan dan pembelajaran model PBI dapat meningkatkan pemahaman konsep siswa melalui hasil belajar yang diperoleh siswa.

\section{PEMBAHASAN}

Penerapan model pembelajaran $P B L$ dan Media Flipcart menunjukkan adanya pelaksanaan kegiatan pembelajaran yang bersifat student centered. Pembelajaran dengan menerapkan model PBL dapat membuat siswa aktif untuk melakukan kegiatan dalam memecahkan masalah tersebut. Siswa dapat mengaplikasikan pengetahuannya untuk melakukan percobaan dalam memecahkan masalah. Hal itu berbeda dengan pelaksanaan kegiatan pembelajaran pra tindakan yang bersifat teacher centered. Siswa hanya mendengarkan penjelasan materi pembelajaran dari guru tanpa melakukan percobaan yang berkaitan untuk menemukan pengetahuannya tentang materi pembelajaran tersebut. Padahal pembelajaran IPA seharusnya dilakukan melalui berbagai kegiatan siswa untuk menemukan sendiri pengetahuannya. Hal itu didukung dengan salah satu tujuan pembelajaran IPA menurut Permendiknas Nomor 22 Tahun 2006 tentang Standar Isi adalah bertujuan agar siswa memiliki kemampuan yaitu mengembangkan keterampilan proses untuk menyelidiki alam sekitar, memecahkan masalah dan membuat keputusan; dan meningkatkan kesadaran untuk berperan serta dalam memelihara, menjaga dan melestarikan lingkungan alam.

Berdasarkan pengertian IPA tersebut, pembelajaran IPA dengan menerapkan model PBL dapat menciptakan pembelajaran yang melatih siswa untuk melakukan berbagai kegiatan dalam memecahkan masalah. Hal tersebut karena model PBL terdiri dari langkah-langkah untuk memecahkan masalah. Langkah-langkah model PBL yang dapat mengaktifkan siswa tersebut didukung dengan pendapat Nurhadi (2004) PBL terdiri dari 5 tahap utama yang dimulai dengan guru memperkenalkan siswa pada suatu masalah dan diakhiri dengan penyajian dan analisis hasil kerja siswa. Sintaks atau tahapan Pembelajaran Berbasis masalah terdapat 5 tahap, yaitu: (1) memberikan orientasi tentang permsalahan kepada peserta didik; (2) mengorganisasikan peserta didik utuk meneliti; (3) membantu investigasi mandiri atau kelompok; (4) mengembangkan dan mempresentasikan artefak dan exhibit; dan (5) menganalisis dan mengevaluasi proses mengatasi masalah.

Selain penerapan model juga diterapkan media flipcard. Penggunaan media pembelajaran dapat mempermudah penanaman konsep. Hal itu didukung oleh pendapat Daryanto (2010) mengemukakan nilai dari media terletak pada tingkat realistiknya dalam proses penanaman konsep, membuat jenjang berbagai jenis media mulai yang paling nyata (konkret) ke yang paling abstrak yaitu kata, diagram, peta, gambar datar, slide, film, model, obyek (benda nyata), dan situasi keseluruhan. Selain itu media flipcart yang berupa bagan dapat memvisualisasikan secara logis dan teratur mengenai fakta pokok atau gagasan. Hal itu didukung oleh pendapat Sudjana menyatakan bahwa bagan adalah kombinasi antara media grafis, gambar, dan foto yang dirancang untuk memvisualisasikan secara logis dan teratur mengenai fakta pokok atau gagasan (Daryanto, 2010). Selanjutnya kegunaan bagan adalah untuk menunjukkan hubungan, keterkaitan, dan perbandingan, jumlah yang relatif, perkembangan tertentu, serta proses pengklasifikasian dan pengorgaisasian.

Hasil belajar siswa adalah hasil yang didapatkan dari pembelajaran yang mengarah pada proses kognitif dan merupakan hasil interaksi dari beberapa faktor antara lain bahan atau materi yang dipelajari, lingkungan, faktor instrumental, dan kondisi

Tabel 1 Tabel Persentase Hasil Belajar Pra Tindakan dan Siklus I

\begin{tabular}{cccc}
\hline Pra Tindakan & Rata-rata nilai Siklus I & Peningkatan Skor & Persentase Peningkatan \\
\hline 74,1 & 79,33 & 5,23 & $7,05 \%$ \\
\hline
\end{tabular}

Tabel 2 Tabel Persentase Hasil Belajar Siklus I dan Siklus II

\begin{tabular}{cccc}
\hline $\begin{array}{c}\text { Rata-rata nilai } \\
\text { Siklus I }\end{array}$ & $\begin{array}{c}\text { Rata-rata nilai } \\
\text { Siklus II }\end{array}$ & Peningkatan Skor & Persentase Peningkatan \\
\hline 79,33 & 81,60 & 2,27 & $2,86 \%$ \\
\hline
\end{tabular}


siswa (Gunawan, dkk., 2014). Hasil belajar siswa juga dipengaruhi oleh kemampuan seorang guru dalam mengelola kelasnya (Gunawan, 2014). Guru yang mampu mengelaborasi kearifan lokal dalam pembelajarannya juga dapat menciptakan iklim kelas yang baik dan mendukung peningkatan hasil belajar siswa (Gunawan, 2012; Gunawan, 2013; Gunawan dan Sulistyoningrum, 2013). Selain itu guru dalam melaksanakan pembelajaran juga harus melakukan variasi mengajar guna meningkatkan motivasi dan hasil belajar siswa (Gunawan dan Benty, 2007). Ragam evaluasi pembelajaran yang digunakan oleh guru juga dapat mempengaruhi hasil belajar siswa (Gunawan, 2011).

\section{SIMPULAN DAN SARAN}

Berdasarkan analisis data dapat disimpulkan bahwa: (1) keterlaksanaan pembelajaran IPA materi ekosostem dengan menerapkan model PBL dan media flipcard pada siklus I dan siklus II masingmasing 76,83 dan 86,84 dengan kriteria baik; dan (2) penerapan model penerapan PBL dan media Flipcart dapat meningkatkan hasil belajar siswa. Berdasarkan hasil penelitian, saran yang diajukan kepada guru adalah agar menerapkan model pembelajaran kooperatif untuk meningkatkan aktivitas dan hasil belajar siswa. Bagi kepala sekolah adalah agar merancang forum kolegial guru dalam meningkatkan profesionalisme mengajar di kelas.

\section{DAFTAR RUJUKAN}

Akbar, S. 2009. Penelitian Tindakan Kelas. Yogyakarta: Cipta Media Aksara.

Kemmis, S., dan Taggart, R. M. 1982. The Action Research Planner. Victoria: Deakin University.

Budiningsih, A. 2005. Belajar dan Pembelajaran. Jakarta: Rineka Cipta.

Daryanto. 2010. Media Pembelajaran. Bandung: Satu Nusa.

Eggen, P., dan Kauchak, D. 2012. Strategi dan Model Pembelajaran. Jakarta: PT Indeks.

Gunawan, I. 2011. Evaluasi Program Pembelajaran. Jurnal Pendidikan, 17(1), 52-70.

Gunawan, I. 2012. Mengembangkan Karakter Bangsa Berdasarkan Kearifan Lokal. Prosiding Seminar Nasional Meretas Sekolah Humanis untuk Mendesain Siswa Sekolah
Dasar yang Cerdas dan Berkarakter, PGSD FKIP Universitas Muhammadiyah Surakarta , 6 Mei.

Gunawan, I. 2013. Revitalisasi Karakter Guru menurut Filosofis Jawa: Sebuah Gagasan Mengembangkan Kepribadian Siswa. Proceeding International Seminar on: Local Wisdom and Character Education for Elementary School Students, IKIP PGRI MADIUN, 6 April.

Gunawan, I. 2014. Pengaruh Supervisi Pengajaran dan Kemampuan Guru Mengelola Kelas terhadap Motivasi Belajar Siswa. Ilmu Pendidikan Jurnal Kajian Teori dan Praktik Kependidikan, 41(1), 44-52.

Gunawan, I., dan Benty, D. D. N. 2007. Musyawarah Guru Mata Pelajaran dan Kemampuan Mengelola Kelas untuk Meningkatkan Motivasi Belajar Siswa. Manajemen Pendidikan, 20(1), 21-31.

Gunawan, I., dan Sulistyoningrum, R. T. 2013. Menggali Nilai-nilai Keunggulan Lokal Kesenian Reog Ponorogo Guna Mengembangkan Materi Keragaman Suku Bangsa dan Budaya pada Matapelajaran IPS Kelas IV Sekolah Dasar. Premiere Educandum, 3(1), 50-87.

Gunawan, I., Suraya, S. N., dan Tryanasari, D. 2014. Hubungan Kemampuan Berpikir Kreatif dan Kritis dengan Prestasi Belajar Mahasiswa pada Matakuliah Konsep Sains II. Premiere Educandum, 4(1), 1-32.

Mulyasa, E. 2007. Menjadi Guru Profesional Menciptakan Pembelajaran Kreatif dan Menyenangkan. Bandung: PT Remaja Rosdakarya.

Nurhadi. 2004. Pembelajaran Kontekstual (Contextual Teaching Learning dan Penerapannya dalam KBK. Malang: Universitas Negeri Malang.

Sudjana, N. 2010. Penilaian Hasil Proses Hasil Belajar Mengajar. Bandung: PT Remaja Rosdakarya.

Peraturan Menteri Pendidikan Nasional Nomor 22 Tahun 2006 tentang Standar Isi untuk Satuan Pendidikan Dasar dan Menengah. 2007. Jakarta: Departemen Pendidikan Nasional. 